\title{
HTLV-I REX Gene
}

National Cancer Institute

\section{Source}

National Cancer Institute. HTLV-I REX Gene. NCI Thesaurus. Code C17365.

Rex gene of the HTLV-I virus. 